\title{
EFFECT OF VARIOUS DIETARY LEVELS OF SUNFLOWER SEED MEAL ON THE PERFORMANCE OF GROWING RABBITS IN SUDANO-SAHELIAN ZONE
}

\author{
A.C. OKONKWO', J.U. IGWEBUIKE ${ }^{1}$, H.U. TARFA'; B.I. OKON ${ }^{2}$ \\ AND B.I. $\mathrm{UMOH}^{2}$ \\ ${ }^{1}$ Department of Animal Science, University of Maiduguri, Maiduguri, Nigeria. \\ ${ }^{2}$ Department of Animal Science, University of Uyo, P.M.B. 1017, Uyo. \\ Received 11 November, 1992; Revised MS received 10 May, 1995; Accepted 16 May, 1995
}

\section{ABSTRACT}

The experiment which lasted for seventy (70) days was conducted to determine the effects of various dietary levels of sunflower seed meal (SSM) on the performance of growing rabbits. Thi v- two (32) indigenous breeds of rabbits o t: ad from small-scale producers were used in " study. They were individually weighed and randomly assigned to the four (4) dietary treatments, in which $0,10,20$ and $30 \%$ of the groundnut cake was replaced by SSM, respectively. The diets contained 2391.76, 2387.44, 2383.12 and 2378.80 $\mathrm{Kcal} \mathrm{ME} / \mathrm{Kg}$ for diets $1,2,3$ and 4 , respectively. The crude protein (CP) was approximately $14.0 \%$ for the four (4) experimental diets. The diets, in mash form were fed to the rabbits ad libitum. There was no significant difference $(P>0.05)$ amongst the treatments in all the parameters examined. Wowever, the incorporation of SSM resulted in 2 cansihterable decrease in feed cost with

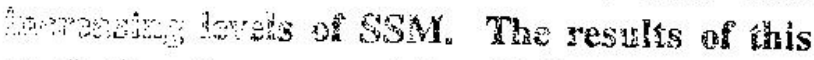
vara $y$ gerore suggest that $30 \%$ or more of the GiNC could be replaced by SSM in the diets of growing rabbits without deleterious effect on performance.

Key words: Sunflower seed meal, Rabbits, Sudano-Sahelian zone.

\section{INTRODUCTION}

The rapid population growth and low animal protein intake are some of the major problems facing developing countries. Oyenuga (1975) reported that an average Nigerian was obtaining about $7.5 \mathrm{~g}$ of animal protein, a level far below the $28 \mathrm{~g}$ recommended by the British Medical Association. The low protein intake may be attributed to inadequate production (FAO,
1970) and high cost of poultry meat, beef, mutton, pork and "bushmeat" which are the traditional sources of animal protein in many developing countries. Thus the search for cheaper sources of animal protein brings rabbits into focus. Rabbits are highly prolific and this makes rabbit rearing an economically viable venture (Abe, 1988). Rabbits compare favourably with other meat producing farm animals; it is as efficient as other farm animals in converting feed into meat (Sanford, 1951). Perhaps accelerated rabbit production may be one of the fastest means of bridging the gap of protein deficiency.

To tap the enormous potentials of rabbits, a sound knowledge of their nutrition is essential. Crampton and Harris (1969) reported that rabbits can digest 65 to $75 \%$ dietary crude fibre. King (1978) suggested that breeding does and young rabbits need about $14 \%$ fibre in their diets, while non-breeding stock can be allowed up to $25 \%$. Energy levels ranging from $40 \mathrm{Kcal}$ to $220 \mathrm{Kcal}$ have been recommended for rabbits (Brody, 1935; Benedict and Lee, 1939). As far as lipids are concerned, a minimum level of $3 \%$ fat (ether extract) is desirable to provide essential fatty acids and to maintain a gloss, sleek hair coat (Cheeke, 1979). King (1978) reported that the minimum level of protein adequate for maintenance of adult non-breeding stock is $10 \%$, and $16-20 \%$ for pregnant, lactating and young growing rabbits. Okorie (1977) suggested that rations for dry does, herd bucks and growing rabbits should contain $12-15 \%$ protein and those of pregnant and lactating does $16-20 \%$. Levels of $16,12,15$ and $17 \%$ for growth, maintenance, pregnancy and lactation are recommended by NRC (1980). 


\section{A. C. OKONKWO ET AL}

The majur protein supplements used in rabbit feeding are collon seed meal (CSM), Soyabean meal, sesame meal, linsced meal and groundnut cake (GNC) (Cheeke, 1979). Little attention is paid to sunflower seed meal (SSM), a protein supplement which may be a cheaper alternative to the aforementioned ones. Therefore, the objective of this study is to examine the effects of various dietary levels of sunflower seed meal (SSM) on the growth and performance of growing rabbits.

\section{MATERIALS AND METHODS}

\section{Experimental Stock}

Thirty-two (32) local breeds of rabbits of mixed sexes obtained from small-scale producers in Maiduguri, were used for the study. They were individually weighed and

\section{TABLE 1: COMPOSITION AND THE CALCULATED ANALYSIS OF THE EXPERIMENTAL DIETS}

\begin{tabular}{|c|c|c|c|c|}
\hline \multirow[b]{2}{*}{ INGREDIENTS } & \multicolumn{4}{|c|}{ DHETS \% } \\
\hline & 1 & 2 & 3 & 4 \\
\hline Sunflower Seed Meal & 0.00 & 1.20 & 2.40 & 3.60 \\
\hline Maize & 8.100 & 8.00 & 8.00 & 8.00 \\
\hline Maize offal & $4+100$ & 44.00 & 44.00 & 44.00 \\
\hline Groundnut Cake & 12000 & 10.80 & 9.60 & 8.40 \\
\hline Groundnut hay & 34.00 & 34.000 & 34.00 & 34.00 \\
\hline Bone meal & 1.00 & 1.00 & 1.00 & 1.00 \\
\hline Premix & 1.00 & 1.00 & 1.00 & 1.00 \\
\hline Total: & 100.00 & 100.00 & 100.00 & 100.00 \\
\hline \multicolumn{5}{|l|}{ Calculated Analysis } \\
\hline $\mathrm{ME}(\mathrm{Kcal} / \mathrm{Kg})$ & 2391.76 & 2387.44 & 2383.12 & 2378.80 \\
\hline Crude Protein (\%) & 14.41 & 14.31 & 14.22 & 14.12 \\
\hline Ether Extract (\%) & 4.94 & 4.90 & 4.87 & 4.82 \\
\hline Crude Fibre (\%) & 17.55 & 17.62 & 17.69 & 17.77 \\
\hline Calcium $(\%)$ & 0.92 & 0.92 & 0.93 & 0.93 \\
\hline Phosphorus (\%) & 0.48 & 0.49 & 0.50 & 0.51 \\
\hline
\end{tabular}

*A vitamin-mineral premix supplying the following/Kg of diet: Vitamin A, 17,000IU; Vitamin D3, 2, 600 IU; Vitamin E, 15IU; Vit. K. 2mg riboflavin 12IU; Vitamin B3,48mg; lysine, 240mg; Methionine 50mg; choline, chloridc, $600 \mathrm{mg}$; manganese, $120 \mathrm{mg}$; iron, $80 \mathrm{mg}$; copper, $10 \mathrm{mg}$; iodine, $2.2 \mathrm{mg}$; seicnium, $0.2 \mathrm{mg}$; antioxidant, $250 \mathrm{mg}$.

TABLE 2: PROXIMATE CHEMICAL COMPOSITION OF THE SUNFLOWER SEED MEAL

\begin{tabular}{ll}
\hline Constituents & $\%$ \\
\hline Moisture & 5.80 \\
Crude Protein & 37.00 \\
Crude Fibre & 11.36 \\
Ether Extract (fat) & 2.60 \\
Ash & 6.85 \\
Nitrogen Free Extract (NIE) & 36.39 \\
Calcium & 0.50 \\
Phosphorus & 0.60 \\
\hline
\end{tabular}

Nigerian Journal of Animal Production 22(2) 1995 randomly assigned to the four (4) experimental diets. Eight rabbits were assigned to each treatment in 4 replicates of two (2) rabbits each. The rabbits were individually housed in cages measuring $30.48 \times 38.1 \times 38.1 \mathrm{~cm}$. Plastic drinkers and feeding troughs were provided in each cage.

Feed and water were supplied ad libitum to rabbits throughout the experimental period of 70 days. All diets were fed in mash form and slightly moistened with water to reduce dustiness.

\section{Experimental diets}

The composition of the experimental diets (treatments) is shown in Table 1. The 
proximate analysis of the SSM samples was carried out according to the A.O.A.C. (1970) methods. Calcium was analysed by atomic absorption spectrophotometry and phosphorus by a colorimetric method (Murphy and Riley, 1963).

\section{The dietary treatments were:}

Diet 1 (Control) - 0\% SSM; Diet $2-10 \%$ of the GNC replaced by SSM; Diet $3-20 \%$ of the GNC replaced by SSM; and Diet $4-30 \%$ of the GNC replaced by SSM

\section{Response Criteria}

Feed consumption, average liveweight gain and feed conversion (gain to feed ratio) of each experimental group were used as the response criteria. Feed intake was measured on daily basis;

Liveweight gain was measured on weekly basis. The prevailing market prices of the feed ingredients were used to estimate the unit cost of the various diets.

\section{Statistical Analysis}

Data were subjected to analysis of variance (Steel and Torric, 1980) using a completely randomized design. Significant differences $(P<0.05)$ between treatment means were determined by the least significant difference (LSD), (Steel and Torrie, 1980).

\section{RESULTS AND DISCUSSION}

The performance data on livewcight gain, feed consumption, feed conversion efficiency (gain to feed ratio) and mortality are Fimmarised in Table 3. The mean tiveweight gain for all the experimental groups was not significant $(P>0.05)$. However, rabbits on diet 4 numerically gained more weight $(P>0.05)$ than the other groups. This is in agreement with the works of Alawa et al. (1989) and Abu and Ekpenyong (1991). Conversely, the liveweight gain recorded in this study was relatively lower than the results reported by Oyawoye (1989), and Abella et al. (1988) for growing rabbits fed soyabean meal, decorticated cotton seed meal and molasses. The final liveweight for all the dietary treatments was not significant $(P>0.05)$. Perhaps the good results obtaincd in relation to the control may be attributed to the similarities between the amino acid profile of GNC and SSM (Church, 1979). Similarly, the feed intake (Table 3) showed no significant difference $(P>0.05)$. This indicates that the addition of SSM to diets 2,3 and 4 did not adversely influence the feed consumption of the rabbits.

The results of this study showed no significant difference $(\mathrm{P}>0.05)$ in feed efficiency amongst the various treatments. Similar observations were made by $\mathrm{Abu}$ and Ekpenyong (1991) while Aduku et al. (1988) and Oyawoye (1989) reported 0.21 and 2.50 respectively. The differences in the results may be due to variations in the ingredients and the high fibre (17.55 to $17.77 \%$ ) content of the experimental diets. King (1978) reported that diets containing more than $14 \%$ crude fibre lower the rate of liveweight gain in growing rabbits. Dafwang (1987) asserted that good quality feeds give better rate of conversion. The mortality data (Table 3 ) indicated that one (1) rabbit died in treatment 2 during the entire experimental period. The death, however, may not be attributed to the inclusion of SSM; the post-mortem examination implicated strangulation as the possible cause of death. Probably the rabbit was strangled in an attempt to escape from the cage.

The economic analysis of the experimental diets is presented in Table 4. The cost prices per $\mathrm{Kg}$ of feed were $\mathrm{N} 2.72, \mathrm{~N} 2.67, \mathrm{~N} 2.62$ and +2.58 for diets $1,2,3$ and 4 respectively. The feed cost per $\mathrm{Kg}$ decreased with increasing levels of SSM. The highest (N2.72) and the lowest ( $\mathrm{N} 2.58$ ) feed cost per $\mathrm{Kg}$ were obtained from diets 1 (control) and 4 respectively. A lot of money could thus be saved by incorporating SSM into diets of growing rabbits. The economic benefit observed in this study was as a result of the price differential between GNC and SSM. At the time this study was conducted, the prevailing prices were $\mathrm{N} 5.00$ and $\mathrm{N} 1.00$ per $\mathrm{Kg}$ of $\mathrm{GNC}$ and SSM respectively. 
A. C. OKONKWO ET AL

\section{TABLE 3: PERFORMANCE DATA OF THE RABBITS FED VARIOUS DIETARY LEVELS OF SUNFLOWER SEED MEAL}

\begin{tabular}{lllll}
\hline DIETS & 1 & 2 & 3 & 4 \\
\hline Percentage replacement of Groundnut cake (\%) & 0 & 10 & 20 & 30 \\
Number of Animals & 8 & 7 & 8 & 8 \\
Initial Liveweight (Kg) & 0.756 & 0.700 & 0.618 & 0.703 \\
Final liveweight (Kg) & \pm 0.071 & \pm 0.061 & \pm 0.089 & \pm 0.048 \\
Liveweight gain (Kg) & 1.110 & 1.022 & 0.968 & 1.167 \\
Feed intake (Kg) & \pm 0.003 & \pm 0.004 & \pm 0.001 & \pm 0.006 \\
Feed efficiency (gain/feed) & 0.354 & 0.322 & 0.350 & 0.464 \\
Mortality & \pm 0.001 & \pm 0.005 & \pm 0.002 & \pm 0.006 \\
& 2.07 & 1.96 & 1.96 & 2.13 \\
\hline
\end{tabular}

TABLE 4: ECONOMICS OF FEEDING SUNFLOWER SEED MEAL (SSM) TO RABBITS.

\begin{tabular}{|c|c|c|c|c|c|c|c|c|c|}
\hline Ingredients & $\begin{array}{l}\mathrm{price} / \mathrm{kg}^{1} \\
(\mathrm{~N})\end{array}$ & $\begin{array}{l}\text { Quantity } \\
(\mathrm{Kg})\end{array}$ & $\begin{array}{l}\text { Price } \\
(\mathrm{N})\end{array}$ & $\underset{(\mathrm{Kg})}{\text { Quantity }^{2}}$ & $\begin{array}{l}\text { Price } \\
\text { (A) }\end{array}$ & $\underset{\substack{\text { Quantity } \\
(\mathrm{Kg})}}{3}$ & $\begin{array}{l}\text { DIETS } \\
\text { Price } \\
\text { (N) }\end{array}$ & $\underset{(\mathrm{Kg})}{\text { Quantity }^{4}}$ & $\begin{array}{l}\text { Price } \\
\left(\mathrm{A}^{\prime}\right)\end{array}$ \\
\hline \multirow{2}{*}{$\begin{array}{l}\text { Sunflower } \\
\text { Sced Meal } \\
\text { Grourdnut Cake } \\
\text { Maize } \\
\text { Maize Offal } \\
\text { Groundnut Hay } \\
\text { Bone Meal } \\
\text { Premix } \\
\text { Total }\end{array}$} & 1.00 & 0.00 & 0.00 & 1.20 & 1.20 & 2.40 & 2.40 & 3.60 & 3.60 \\
\hline & $\begin{array}{l}5.00 \\
5.00 \\
2.00 \\
2.00 \\
2.00 \\
14.00\end{array}$ & $\begin{array}{l}12.00 \\
8.00 \\
44.00 \\
34.00 \\
1.00 \\
1.00 \\
100.00\end{array}$ & $\begin{array}{l}60.00 \\
40.00 \\
88.00 \\
68.00 \\
2.00 \\
14.00 \\
272.00\end{array}$ & $\begin{array}{l}10.80 \\
8.00 \\
44.00 \\
34.00 \\
1.00 \\
1.00 \\
100\end{array}$ & $\begin{array}{l}54.00 \\
40.00 \\
88.00 \\
68.00 \\
2.00 \\
14.00 \\
267.20\end{array}$ & $\begin{array}{l}9.60 \\
8.00 \\
44.00 \\
34.00 \\
1.00 \\
1.00 \\
100.00\end{array}$ & $\begin{array}{l}48.00 \\
40.00 \\
88.00 \\
68.00 \\
2.00 \\
14.00 \\
262.40\end{array}$ & $\begin{array}{l}8.40 \\
8.00 \\
44.00 \\
34.00 \\
1.00 \\
1.00 \\
100.00\end{array}$ & $\begin{array}{l}42.00 \\
40.00 \\
88.00 \\
68.00 \\
2.00 \\
14.00 \\
257.60\end{array}$ \\
\hline Price/Kg Feed(A) & & \multicolumn{2}{|l|}{2.72} & \multicolumn{2}{|l|}{2.67} & \multicolumn{2}{|l|}{2.62} & \multicolumn{2}{|c|}{2.58} \\
\hline
\end{tabular}

$1=$ Prevailing Market Price at the time the study was conducted.

\section{CONCLUSION}

The results of this study show that up to $30 \%$ of GNC could be replaced by SSM in the diets of growing rabbits without a deleterious effect on performance. It is speculated that with more research, higher levels of SSM could be incorporated into the diets of rabbits. This will be economically viable in view of the cheaper cost of procuring SSM. Finally, the current prices of beef, mutton, goat and poultry meats underscore the need to embark on extensive rabbit production as a means of raising animal protein intake of Nigerians and people in other developing countries of the world.

\section{REFERENCES}

ABE, R. O. (1988). Questions and answers of Rabbit Raising T.A.A. Printing Company, Ibadan 34 pp.

ABDELLA, H.M., SHALASH, S.M; BOULES, N.Z. AND SELIM, A.D. (1988). Effect on growing rabbits of feeding different levels of crude protein J. Appl. Rabbit Res. 2 (4): 252 $-256$.

ABU, O.A. and EKPENYONG (1991). Utilization of Dried Palm Oil Mill Effluent by Young growing Rabbits (in Press).

ADUKU, A., DIM, N.I. and AGANGA, A.A. (1988). Note on comparative evaluation of palm kernel meal, Peanut meal and Sunflower meal in diets for weaning rabbits. J. Appl. Rabbits Res. 2 (4): 264 - 265.

ALAWA, J.P., KARIBI - BOTOYE, NDUKWE, F.O. and BEREPUBO, N.A. (1989). Effects of varying proportions of 
Brewers' dried grains on the growth performance of young rabbits. J. Appl. Rabbit Res. 12 (4): 252 - 255.

A.O.A.C. (ASSOCIATION OF OFFICIAL ANALYTICAL CHEMISTS) (1970). Official Methods of Analysis 11th ed. Washington, D.C.

BENEDICT, F.G. and LEE, P.K. (1939). Effects of locally produced sunflower oil meal as partial protein supplement on growth, feed efficiency and carcass quality of growing finishing pig. J. of Agric. Assoc. of China (Taiwan), 122: 79 - 90.

BRODY, S. (1935). The relationship between feeding standards and basal metabolism. State College Pennsylvania, U.S.A.pp. 12 - 16.

CHEEKE, P.R. (1979) Nutrition of the Domestic Rabbits in: Livestock Feeds and Feeding. Church, D.C. (Ed), O. and B: Books, Inc. Corvallis, Oregon, U.S.A.

CHURCH, D.C. (1979). Livestock Feeds and Feeding. $O$ and $B$ Books Inc. Corvallis, Oregon; U.S.A.

CRAMPTON, E.W. and HARRIS, L.A. (1969). Applied Animal Nutrition. 2nd ed. W.H. Freeman and Co., San Francisco 213 pp.

DAFWANG, I.I. (1987). Essentials of Poultry Management Livestock and Poultry Management course for livestock and veterinary officers organised by Agricultural Extension and Research Liaison Services, A.B.U., Samaru, Zaria pp. 98 - 112.

FOOD AND AGRICULTURAL ORGANISATION (FAO) (1970). Report of the Second World Food Congress. The Haque. 16-30 June, FAO, Rome.
SEED MEAL TO RABBITS

IBEAWUCHI, J.A. and FAJOYITAN, A.O. (1986). Rabbit Industry a source of meat for human consumption. Livestock farmer. National Veterinary Research Institute, Vom.

KING, J.O.L. (1978). The care and management of farm animals. Bailliere Tindal Great Britain 254 pp.

MURPHY, J. and RILEY, J. (1963). A modified single solution method for the determination of phosphate in natural waters. Anal. Chem. Acta 27: 31 - 35 .

National Research Council (N.R.C., 1980). Mineral tolerance of domestic animals. Nat. Acad. Sci., Washington, D.C.

OKORIE, J.U. (1977). A guide to livestock production in Nigeria. Macmillan Education, London $212 \mathrm{pp}$.

OYAWOYE, E.O. (1989). The case of increased rabbit production in Nigeria. Agro-Forum 1 (1): 6-7.

OYENUGA, V.A. (1975): The challenge of 1980 in Nigeria Agricultural (Livestock) sector. Nig. J. of Anim. Prod. 2 (1): 7 - 11.

SANFORD, J. C. (1951). The domestic Rabbit. 3rd ed. Lockwood and staples, London. pp. 3 - 10 .

STEEL, R.G.D. and TORRIE, J.H. (1980). Principles and Procedures of statistics. 2nd ed. McGraw - Hill Book Co. Inc. New York. 